\title{
New records of Dacrymycetes (Fungi: Basidiomycota) from the Cerrado Biome (Brazilian Savanna) and Midwest Region, Brazil
}

\author{
Renato L. M. Alvarenga, Solange Xavier-Santos \\ Programa de Pós-Graduação em Recursos Naturais do Cerrado (RENAC), Universidade Estadual de Goiás, Campus de Ciências Exatas e \\ Tecnológicas, BR 153 n³.105, Fazenda Barreiro do Meio, CEP 75132-903, Anápolis, GO, Brazil \\ Corresponding author: Renato L. M. Alvarenga, renatolma@gmail.com
}

\begin{abstract}
The information about the distribution of 5 species of jelly fungi of Dacrymycetes, recorded in different locations of the Cerrado biome, is updated or expanded. Dacrymyces chrysospermus Berk. \& M.A. Curtis, Dacryopinax elegans (Berk. \& M.A. Curtis) G.W. Martin, D. maxidorii Lowy and D. spathularia (Schwein.) G.W. Martin are the first records for the Cerrado and the Brazilian Midwest Region. Calocera cornea (Batsch) Fr. is being reported for the first time in Goiás state and newly reported for the Federal District, after 40 years.
\end{abstract}

\section{Key words}

Dacrymycetaceae; Dacrymycetales; geographic distribution; jelly fungi.

Academic editor: Panu Kunttu | Received 26 February 2017 | Accepted 6 June 2017 | Published 18 August 2017

Citation: Alvarenga RLM, Xavier-Santos S (2017) New records of Dacrymycetes (Fungi: Basidiomycota) from the Cerrado Biome (Brazilian Savanna) and Midwest Region, Brazil. Check List 13 (4): 335-342. https://doi.org/10.15560/13.4.335

\section{Introduction}

Dacrymycetes is a monophyletic clade belonging to the phylum Basidiomycota, with evolutionary origin estimated at 280-360 MYA (Dentinger et al. 2009). Dacrymycetes is a sister group of the Agaricomycetes in the Agaricomycotina clade (Hibbett 2006, Hibbett et al. 2007) and has 1 order and 1 family (Dacrymycetales: Dacrymycetaceae), 13 genera and 156 species (Oberwinkler 2014, Kirk 2015).

Dacrymycetes is macroscopically characterized by gelatinous or cartilaginous basidioma, ranging from strictly corticoid to pustulate, cupulate, cyphelloid, stalked-capitate or clavarioid, with color varying from yellow to orange and brown. Microscopically, it is characterized by frequent, modified, thick-walled hyphae on the abhymenial surface, denominated marginal hairs, forked (bifurcate) basidia (except in Dacrymyces unisporus (L.S. Olive) K. Wells), basidiospores with transverse septation in mature stages, and germination with microconidia or hyphae, but without secondary spores (McNabb 1964, 1965a, 1965b, 1965c, 1965d, 1965e, 1966, Oberwinkler 2014, Shirouzu et al. 2009). Species that belong to this class are brown-rot fungi and potent cellulose degraders, with their enzymatic activity comparable to large hydrolase producers found in species of the old order Aphyllophorales (Worrall et al. 1997).

In Brazil, 15 species are reported, but the knowledge about the group is limited to few studies. Teixeira (1945) and Viégas (1945) reported Dacryopinax spathularia (Schwein.) G. W. Martin.; Lowy (1971) reported 8 species (Arrhytidia involute (Schwein.) Coker, Calocera cornea (Batsch) Fr., Cerinomyces lagerheimii (Pat.) McNabb, Dacrymyces deliquescens var. ellisii (Coker) L. L. Kenn), 


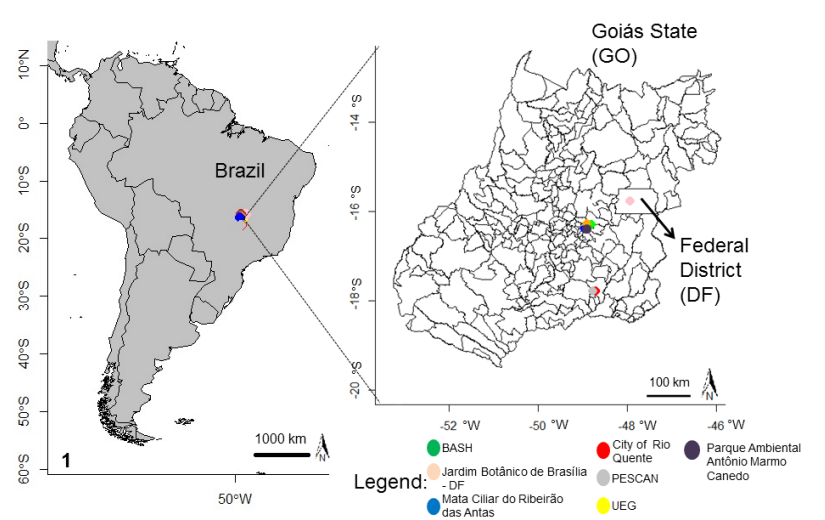

Figure 1. Distribution of the sites sampled in Goiás state and Federal District. Map of South America, showing collection areas in Brazil (left), and Collection sites in Goiás state and Federal District. Maps produced with R Software.

Dacryopinax elegans (Berk. \& M. A. Curtis) G. W. Martin, D.indacocheae Lowy, D. spathularia (Schwein.) G. W. Martin, Ditiola radicata (Alb. \& Schwein.) Fr.), and later (Lowy 1981) described D.maxidorii Lowy; Sotão et al. (2002) reported Calocera cornea, D. maxidorii Lowy; Campos (2005) D. maxidorii Lowy; Sobestiansky (2005) Dacrymyces enatus var. macrosporus L. L. Kenn., D elegans (Berk. \& M. A. Curtis) G. W. Martin, D. spathularia (Schwein.) G. W. Martin; Meijer (2006) reported 8 species (Cerinomyces lagerheimii (Pat.) McNabb, Dacrymyces chrysospermus Berk. \& M.A. Curtis, D. stillatus Nees, Dacryopinax elegans (Berk. \& M. A. Curtis) G. W. Martin, D. martinii Lowy, Dacryopinax spathularia (Schwein.) G. W. Martin, Guepiniopsis buccina (Pers.) L. L. Kenn.; Trieveiler-Pereira et al. (2009), Calocera cornea (Batsch) Fr.; and, most recently, Shirouzu et al. (2013) described Calocera arborea Shirouzu.

The present study expands the knowledge of the geographical distribution of Dacrymycetes species in Brazil.

\section{Methods}

Specimens were collected during 2008-2014 in different locations in Cerrado areas of Goiás state: Anápolis, campus of the Universidade Estadual de Goiás, Reserva Ecológica da Trilha do Tatu; Parque Ambiental Antônio Marmo Canedo, both in mesophyll forest; Mata de Galeria do Ribeirão das Antas, AmBev, Cebrasa Branch, in gallery forest; Terezópolis de Goiás, Reserva Particular do Patrimônio Natural (RPPN), Fazenda Santa Branca; Goiânia, Campus II of the Universidade Federal de Goiás, Bosque Auguste Saint-Hilaire (BASH), both in mesophyll forest; Caldas Novas, Parque Estadual da Serra de Caldas Novas (PESCAN), and Rio Quente, in mesophyll and semi-deciduous forest. Specimens were also collected at 1 area in the Federal District: Brasília, Jardim Botânico de Brasília, mesophyll forest (Fig. 1).

The basidiomata underwent dry and wet preservation and were deposited at the Herbarium of Universidade Estadual de Goiás (HUEG). Macro- and microscopic taxonomic features were studied, including the general aspect of the basidioma, hymenial surface, basidia, and basidiopores according to $\mathrm{McNabb}(1964,1965 \mathrm{a}, 1965 \mathrm{~b}$, 1965c, 1965d, 1965e, 1973), Lowy (1971, 1981), and Shirouzu et al. (2009).

\section{Results}

Calocera cornea (Batsch) Fr., Stirpes Agri Femsionensis 5: 67. 1827.

= Clavaria cornea Batsch, Elenchus fungorum: 139. 1783.

Figures 2-6

Basidiomata scattered, cylindrical, subulate, simple, slightly branched, dendroid, white to yellow, soft-cartilaginous, (1)5-15 × (0.5)1-2 mm. Structure showing in transverse section a central core of compact parallel hyphae surrounded by a zone of loosely interwoven hyphae enclosed by the hymenium. Internal hyphae branched, thin- or thick-walled, septate, sub-hyaline, $2-4.5 \mu \mathrm{m}$ in diameter, without clamp connections. Hymenium amphigenous. Probasidia cylindrical to clavate, pale yellow, 20-28 (35) $\times 2-4 \mu \mathrm{m}$, becoming bifurcate. Metabasidia cylindrical to clavate, becoming bifurcate 16-26 × 2-3 $\mu \mathrm{m}$, basidiospores subglobose to reniform, with an apiculum at the base, thin-walled, sub-hyaline, 7-10 $\times 2-3 \mu \mathrm{m}, 0-1$ septate.

Material examined. BRAZIL, Federal District: Jardim Botânico de Brasília, 01.XII.2010. Alvarenga, R.L.M. (32), HUEG 10503; Goiás: Rio Quente (17²7'35" S, 048 47'36" W), 01.V.2008, Xavier-Santos, S. (2501), HUEG 8438; Caldas Novas (17² $2^{\prime} 53^{\prime \prime}$ S, 048 43'46" W), 23.I.2008, Xavier-Santos, S. (2293), HUEG 8402; City of Anápolis, Reserva Ecológica do Campus da Universidade Estadual de Goiás (16¹9'37" S, 048 57'10" W) 10.XII.2010, Xavier-Santos, S. (4501), HUEG 8459; 04.X.2010, Alvarenga, RLM. (42), HUEG 8482; Alvarenga, RLM. (105), HUEG 10504; Mata Ciliar do Ribeirão das Antas, AmBev (Filial Cebrasa) (16 $17^{\circ} 38^{\prime \prime} \mathrm{S}$, 048 48'54" W), 29.III.2011, Xavier-Santos, S. (4784), HUEG 10506 (associated to myxomycetes Arcyria denu$\operatorname{data}(\mathrm{L}$.$) Wettst.).$

Notes on distribution. Cosmopolitan. In Brazil, this species is recorded in the states of Amazonas, Pará, São Paulo, Paraná, Santa Catarina, and Rio Grande do Sul, including the, in Amazon, Atlantic Forest and Cerrado biomes (Lowy 1971, Campos et al. 2005, Sobestiansky 2005, Trierveiler-Pereira et al. 2009). The new records extend the geographic distribution of $C$. cornea to Goiás state and include the second record from the Cerrado biome and the only record from the Federal District in more than 40 years.

\section{Dacrymyces chrysospermus Berk. \& M.A. Curtis,} Grevillea 2 (14): 20.1873.

Figures 7-8

Basidiomata scattered or gregarious, flabellate or stoutly stipitate with a spathulate, yellow, firm-gelatinous, $4 \mathrm{~cm}$ 

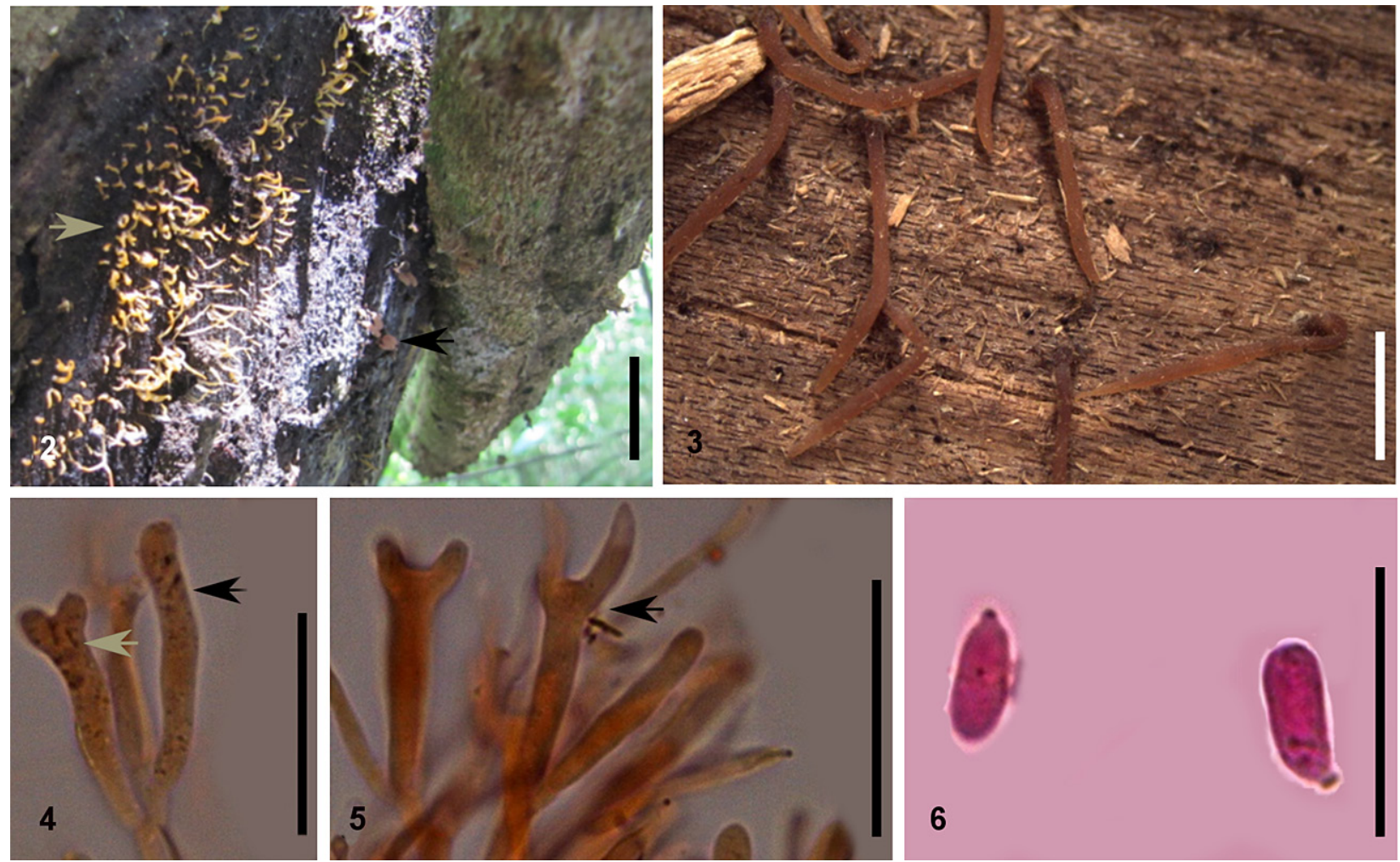

Figure 2-6. Calocera cornea. 2. Basidiomata of Calocera cornea when fresh (gray arrow) associated to sporacarp of myxomycetes Arcyria denudata (black arrow): HUEG 10506, scale bar $=1 \mathrm{~cm}$. 3. Basidioma when dried (HUEG 8438), scale bar $=2 \mathrm{~mm}$. 4. Probasidia (black arrow) and metabasidia (gray arrow), scale bar $=20 \mu \mathrm{m}$. 5. Immature metabasidia (black arrow), scale bar $=20 \mu \mathrm{m}$. 6. Basidiospores, scale bar $=20 \mu \mathrm{m}$.

high, 6-13 $\mathrm{mm}$ in height. Internal hyphae branched, thinwalled, gelatinous, septate, pale yellow, $2-3 \mu \mathrm{m}$ diameter, without clamp connections. Hymenium limited to upper surface of the pileus. Probasidia cylindrical to clavate, yellow to orange, 50-66 × 7-9 $\mu \mathrm{m}$, becoming bifurcate. Basidiospores cylindrical to curved-cylindrical, with an apiculum at the base, thin-walled, yellow, 16-22 × 6-8 $\mu \mathrm{m}, 3-7$ septate.

Material examined. BRAZIL, Federal District: Jardim Botânico de Brasília (1552'12"S, 04750'59" W), 01.XII.2010. Alvarenga, R.L.M. (25), HUEG 8382;
Alvarenga, R.L.M. (27), HUEG 8383; Alvarenga, R.L.M. (28), HUEG 8394; Alvarenga, R.L.M. (33), HUEG 8385.

Notes on distribution. Cosmopolitan. In Brazil, this species is known only from Paraná state (Meijer 2006), in the Atlantic Forest biome. It is here newly recorded for Brazil, after 9 years, and this is the first record for the Cerrado biome and for the Midwest Region.

Additional note. Due to compaction and dryness of the gelatinous matrix during the drying process of the samples, it was impossible to perform photo-documentation of microscopic characteristics.
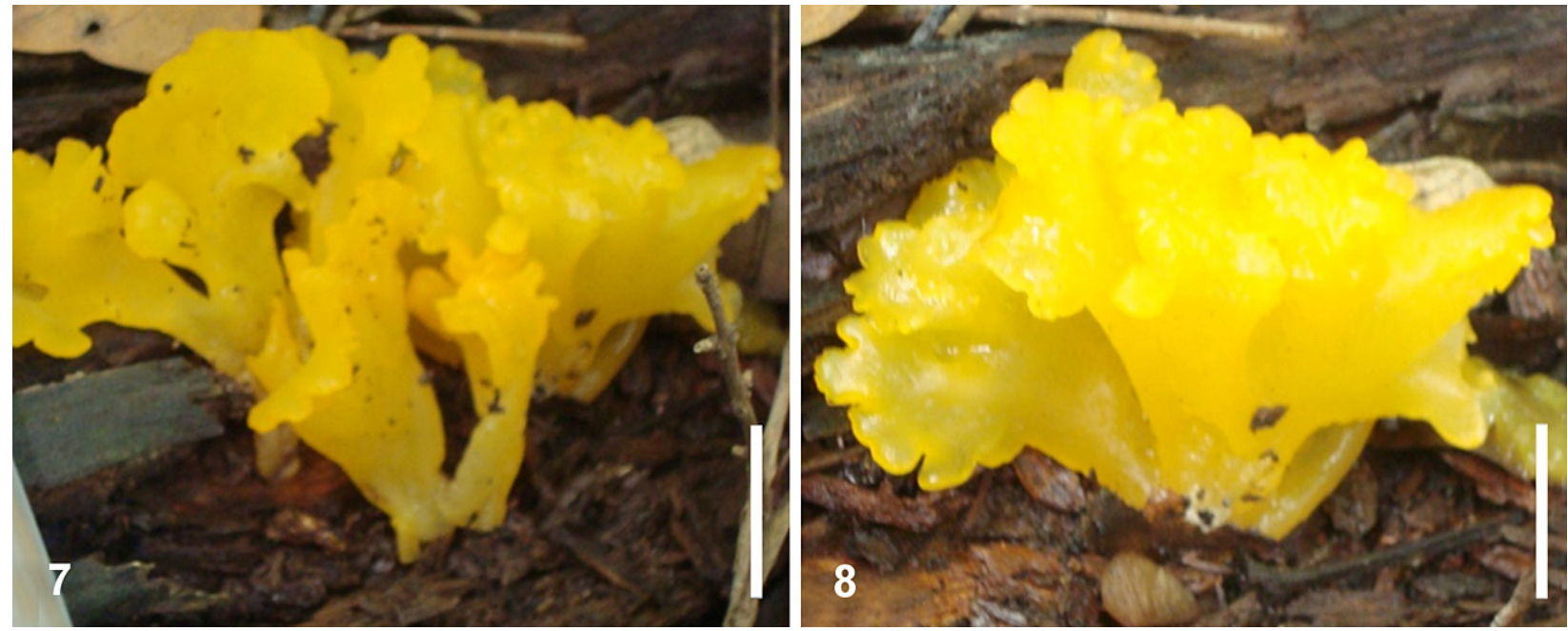

Figures 7, 8. Dacrymyces chrysospermus, basidiomata when fresh. 7. HUEG 8382. 8. HUEG 8394. Scale bar $=1 \mathrm{~cm}$. 

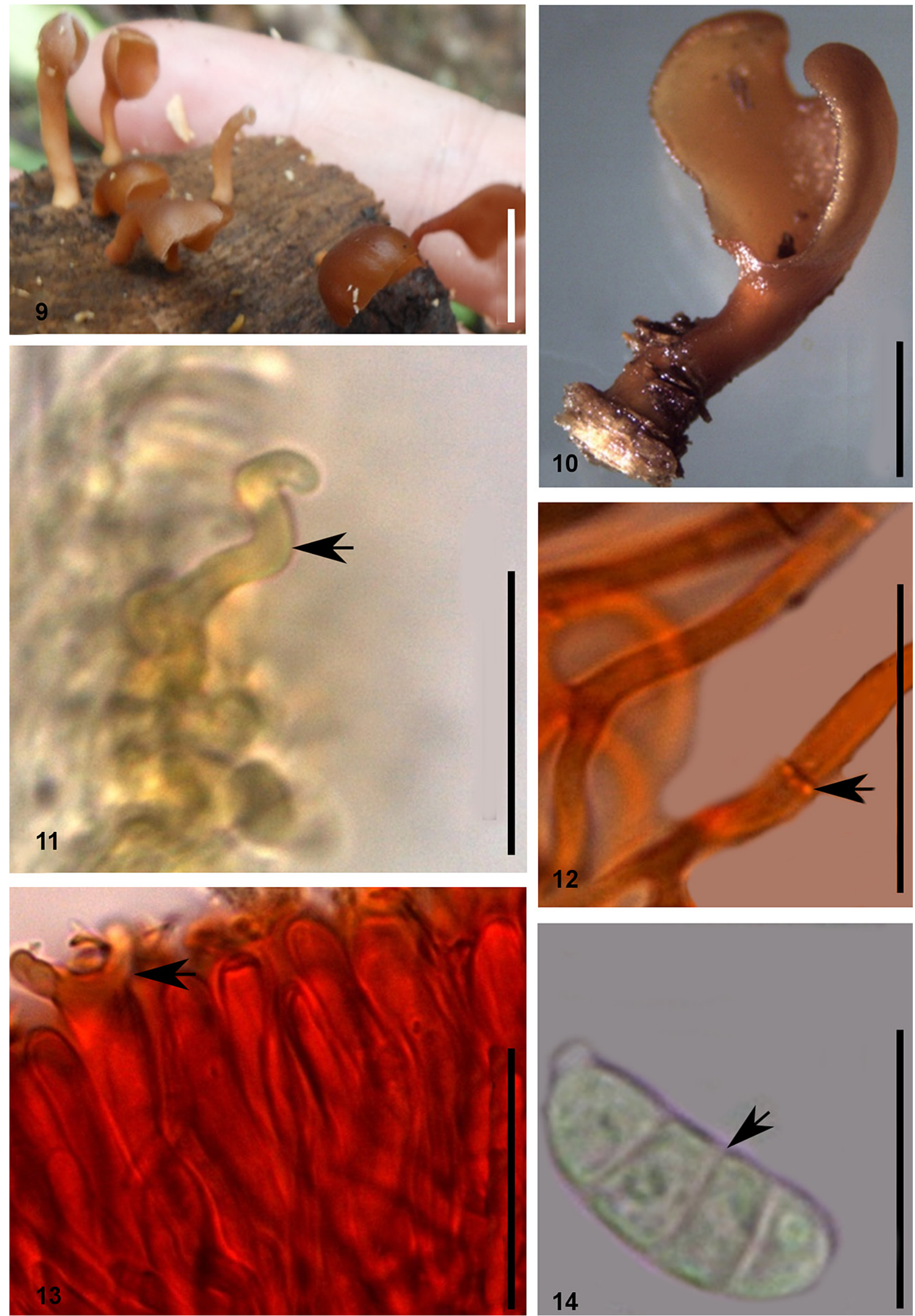

Figure 9-14. Dacryopinax elegans. 9, 10. Basidiomata when fresh (HUEG 10499), scale bars $=1 \mathrm{~mm}$ and $2 \mathrm{~mm}$ respectively. 11. Marginal hairs (black arrow), scale bar $=10 \mu \mathrm{m}$. 12. Hyphae without clamp-connection (black arrow), scale bar $=10 \mu \mathrm{m}$. 13. Hymenium with immature metabasidia (black arrow), scale bar $=10 \mu \mathrm{m}$. 14. Basidiospore with 3 septa (black arrow), scale $=10 \mu \mathrm{m}$. 

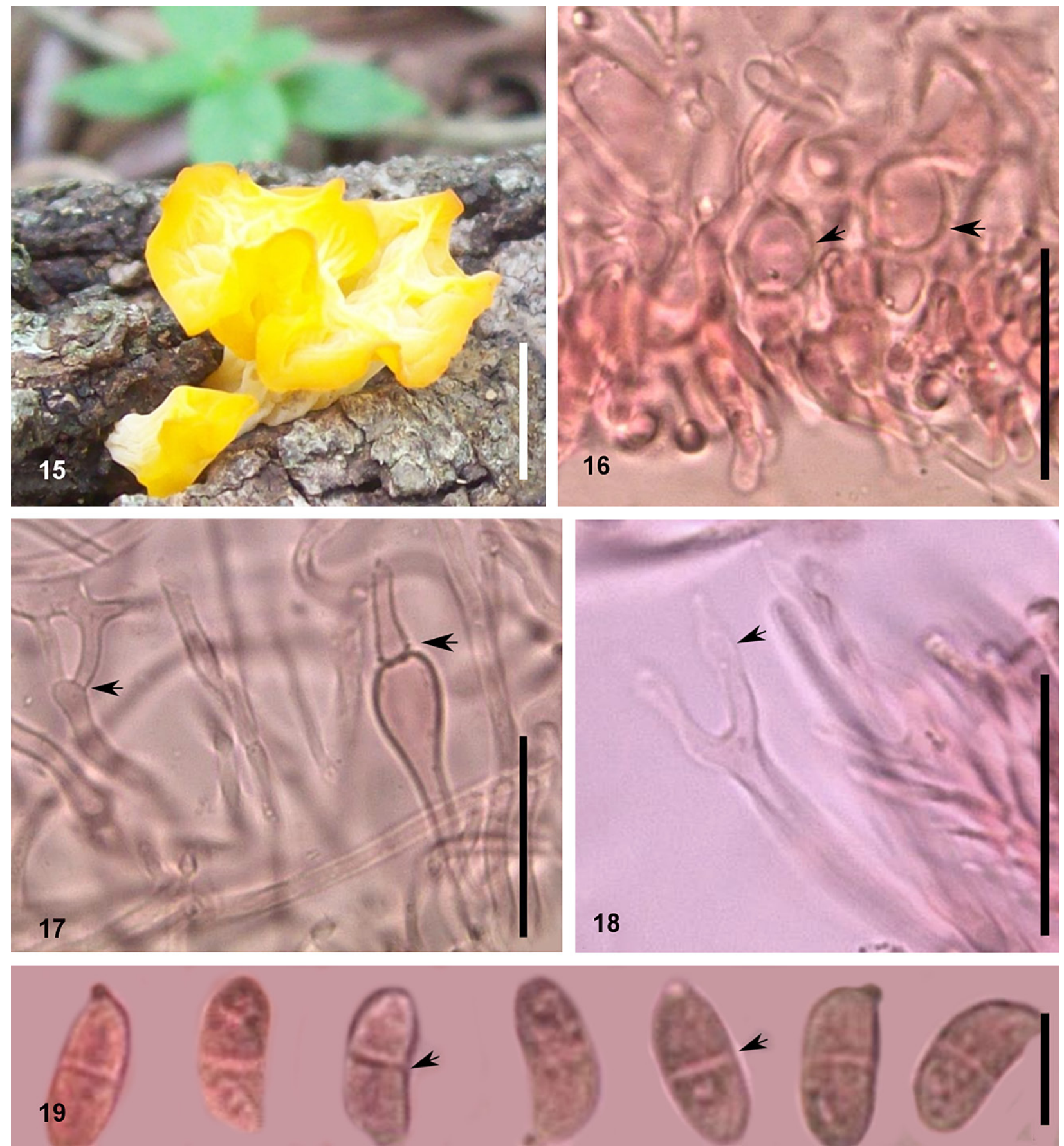

Figures 15-19. Dacryopinax maxidorii. 15. Basidiomata when fresh (HUEG 10505), scale bar = $1 \mathrm{~cm}$. 16. Marginal hairs inflated (black arrow), scale bar $=20 \mu \mathrm{m}$. 17. Hyphae without clamp connection (black arrow), scale bar $=20 \mu \mathrm{m}$. 18. Metabasidia (black arrow), scale bar $=20 \mu \mathrm{m}$. 19. Morphological variation among basidiospores with 1 septation, scale bar $=5 \mu \mathrm{m}$.

Dacryopinax elegans (Berk. \& M.A. Curtis) G.W. Martin, Lloydia 11 (2): 116. 1948.

$\equiv$ Guepinia elegans Berk. \& M.A. Curtis, Hooker's Journal of Botany and Kew Garden Miscellany 1: 239. 1849.

Figures 9-14

Basidiomata scattered or gregarious, tough-gelatinous, pileus spreading-orbiculate, dark brownish when fresh, drying blackish, horny, stipe up to $6(10) \times 5 \mathrm{~mm}$, brownish-tomentose, hairs numerous, septate, thick-walled, hymenium unilateral, inferior, smooth, abhymenium coarsely brown-tomentose, hyphae without clamp connections. Probasidia cylindrical to clavate $35-41 \times 3-5$ $\mu \mathrm{m}$, metabasidio cylindrical to clavate, aseptade, bifurcate with $23 \times 3 \mu \mathrm{m}$. Basidiospores curved-cylindrical, 1-3 septate with $12-16 \times 4-6 \mu \mathrm{m}$.

Material examined. BRAZIL, Goiás: Anápolis, Parque Ambiental Antônio Marmo Canedo - Parque da Matinha (16²18'33" S, 048 57'18" W), 13.XII.2014, Alvarenga, RLM (210), HUEG 10499; Goiânia, Campus II of the Universidade Federal de Goiás, Bosque Auguste SaintHilaire (BASH) (16³6'15" S, 049 $\left.15^{\prime} 39^{\prime \prime} \mathrm{W}\right), 07 . X .2013$, Naves, L.R. (222), HUEG 10498.

Notes on distribution. Pantropical. In Brazil this spe- 

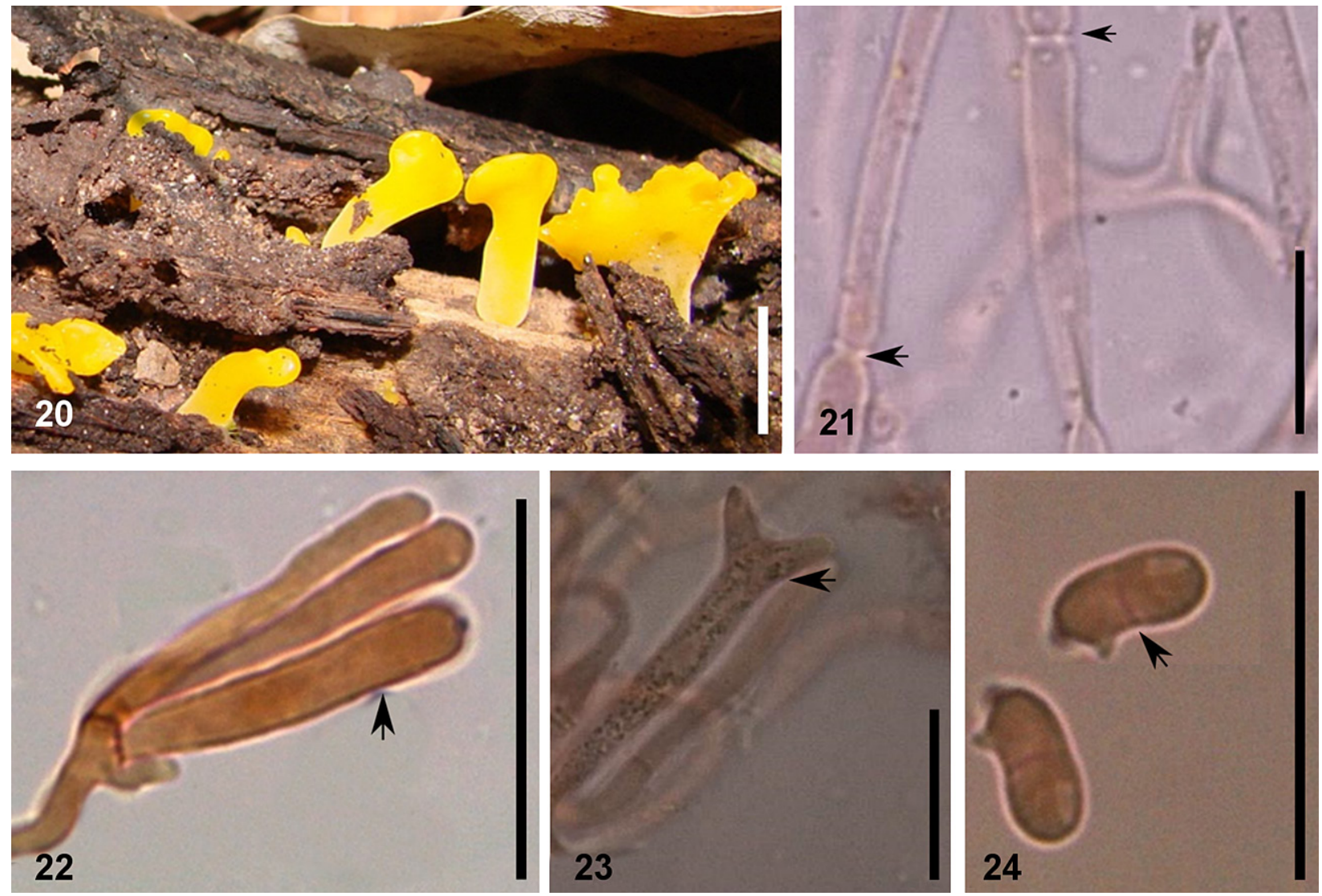

Figures 20-24. Dacryopinax spathularia. 20. Basidiomata (HUEG 8403), scale bar $=1 \mathrm{~cm}$. 21. Hyphae without clamp connection (black arrow), scale bar $=10 \mu \mathrm{m}$. 22. Probasidia (black arrow), scale bar $=20 \mu \mathrm{m}$. 23. Immature metabasidia (black arrow), scale bar $=10 \mu \mathrm{m} .24$. Basidiospore with septation (black arrow) scale bar $=20 \mu \mathrm{m}$.

cies is reported for the in the states of Amazonas, São Paulo, Rio de Janeiro, Paraná and Rio Grande do Sul states, in areas of the Amazon and Atlantic Forest biomes (Lowy 1971, Sobestiansky 2005, Meijer 2006, Sobestiansky 2005, Meijer 2006). Dacryopinax elegans is here reported for the first time in the Cerrado biome and in the Midwest Region.

Dacryopinax maxidorii Lowy. Mycotaxon 13 (2): 428. 1981.

Figures 15-19

Basidiomata, when fresh, stipitate bearing sinuate flabellate, orange-yellow, at the sterile surface of basidiomata, soft-cartilaginous, $12-25 \times 12-23 \mathrm{~mm}$. Internal hyphae branched, thin-walled, septate, 1.8-3.4 $\mu \mathrm{m}$ diameter, without clamp connections. Hymenium unilateral. Probasidia cylindrical to clavate, pale yellow, 31-37.2 $\times$ 4-5.3 $\mu \mathrm{m}$, becoming bifurcate. Basidiospores curvedcylindrical, with an apiculum at the base, thin-walled, pale yellow, (8)9-10 × 4-5 $\mu \mathrm{m}, 0-1$ septate.

Material examined: BRAZIL, Goiás: City of Rio Quente (17 $47^{\prime} 35^{\prime \prime}$ S, 048 $47^{\prime} 36^{\prime \prime}$ W), Fazenda Particular, Mata Estacional Semidecidual. 28.III.2009, Xavier-Santos, S. (3541), HUEG 10505; Terezópolis de Goiás, Reserva Particular do Patrimônio Natural (RPPN) Fazenda Santa Branca $\left(16^{\circ} 25^{\prime} 09^{\prime \prime} \mathrm{S}, 49^{\circ} 05^{\prime} 39^{\prime \prime} \mathrm{W}\right) .03 . V .2014$, XavierSantos, S. (6081), HUEG 10507.
Additional material examined. BRAZIL, Amazonas: km 405 Manaus-Porto Velho road. 16.IX.1980. Lowy, B. \& Coelho, D. (BR190) INPA 101201. Det. Lowy, B [Holotype].

Notes on distribution. Previously known only in the Amazon biome of Amazonas and Pará states, northern Brazil (Lowy 1981, Sotão et al. 2003, Campos et al. 2005), this species is reported here for the first time from the Cerrado biome of Goiás state, Midwest Region.

Dacryopinax spathularia (Schwein.) G.W. Martin, Lloydia 11 (2): 116. 1948.

$\equiv$ Guepinia spathularia (Schwein.) Fr., Elenchus Fungorum 2: 32. 1828. Figures 20-24

Basidiomata scattered or gregarious, spathulate, stipitate bearing sinuate flabellate to petaloid pileus, orange, white-yellow at the sterile surface of basidiomata, softcartilaginous, 5-16 mm high, $0.6-2 \mathrm{~mm}$ diameter at stipe. Internal hyphae branched, thin-walled, septate, pale yellow, 1-2.5 $\mu \mathrm{m}$ diam, without clamp connections. Hymenium unilateral. Probasidia cylindrical to clavate, pale yellow, 20-38 $\times 2-4 \mu \mathrm{m}$, becoming bifurcate. Basidiospores subglobose to reniform, with an apiculum at the base, thin-walled, pale yellow, 9-10×3-4 $\mu \mathrm{m}, 0-1$ septate.

Material examined. BRAZIL, Goiás: Caldas Novas (17 $42^{\prime} 53^{\prime \prime}$ S, $048^{\circ} 43^{\prime} 46^{\prime \prime}$ W), 01.V.2008, Xavier-Santos, S. (2500), HUEG 8400, (2800), HUEG 8403; City of Rio 
Quente (1747'35" S. 048 47'36" W), 22.I.2008, XavierSantos, S. (2207), HUEG 8419; City of Rio Quente (1747'35" S, 04847'36" W), 24.I.2008, Xavier-Santos, S. (2483), HUEG 8426; (2232), HUEG 10501; (3281), HUEG 10502; (3283), HUEG 10500; Anápolis, Reserva Ecológica do Campus da Universidade Estadual de Goiás (16²19'37" S, 048 57'10" W) , 28.IX.2009, Xavier-Santos, S. (4295), HUEG 8461; 10.XII.2010, Xavier-Santos, S. (4508), HUEG 8441; Mata Ciliar do Ribeirão das Antas, AmBev (Filial Cebrasa) (16 $\left.17^{\circ} 38^{\prime \prime} \mathrm{S}, 048^{\circ} 48^{\prime} 54^{\prime \prime} \mathrm{W}\right)$, 26.X.2010, Xavier-Santos, S. (4564), HUEG 8416; (4553), HUEG 8415.

Notes on distribution. Pantropical. In Brazil, this species is recorded in the states of Amazonas, Rio de Janeiro, São Paulo, Paraná and Rio Grande do Sul, where it occurs in the Amazon and Atlantic Forest biomes [Teixeira 1945, Viégas 1945 (as Guepinia spathularia), Lowy 1971, Sobestiansky 2005, Meijer 2006]. The new record is the first of this species from the Cerrado biome and from the Midwest Region.

\section{Discussion}

Occurrence data on this group in Brazil is scarce, which possibly derives from the difficulty in maintaining the basidiomata during the drying process and mainly from the scarcity of specialists in the country.

The present study explores a practically unexplored region and adds to the knowledge regarding the geographic distribution of Dacrymycetes in Brazil. This study reports 4 new records of species from the Midwest Region and from the Cerrado biome (Dacrymyces chrysospermus, Dacryopinax elegans, D. maxidorii and D. spathularia), and 5 new occurrences for Goiás state (including Calocera cornea among those aforementioned). Not since 1971, when Calocera cornea was reported from the Federal District, has a jelly fungi (Dacrymycetes) been reported from the Midwest Region of Brazil. Thus, after a 44-year hiatus, the jelly fungi of the Midwest Region are once again discussed in the literature.

\section{Acknowledgements}

We thank Fundação de Amparo à Pesquisa do Estado de Goiás (FAPEG) for the Masters scholarship awarded to the first author and for the financial support (Process no. 201210267001098).

\section{Authors' Contributions}

All the authors have contributed equally in to improving the text, in particular SXS collected most specimens, and RLMA did macro- and microscopical analysis.

\section{References}

Campos EL, Sotão HMP, Cavalcante MAQ, Luz AB (2005) Basidiomycetes de Manguezais da APA de Algodoal-Maiandeua, Pará,
Brasil. Boletim do Museu Paraensi Emílio Goeldi, série Ciências Naturais 1: 141-146.

Dentinger BTM, Ammirati JF, Both EE, Desjardin DE, Halling RE, Henkel TW, Moreau PA, Nagasawa E, Soytong K, Taylor AF, Watling R, Moncalvo JM, van Driel KGA, Humabel BM, Verkleij AJ, Stalpers J, Müller WH, Boekhout T (2009) Septal pore complex morphology in the Agaricomycotina (Basidiomycota) with emphasis on the Cantharellales and Hymenochaetales. Mycological Research 113: 559-576. https://doi.org/10.1016/j. mycres.2008.12.007

Hibbett DS (2006) A phylogenetic overview of the Agaricomycotina. Mycologia 98: 917-925. https://doi.org/10.3852/mycologia.98.6.917

Hibbett DS, Binder M, Bischoff JF, Blackwell M, Cannon PF, Eriksson OE, Huhndorf S, James T, Kirk PM, Lücking R, Lumbsch T, Lutzoni F, Matheny PB, Mclaughlin DJ, Powell MJ, Redhead S, Schoch CL, Spatafora JW, Stalpers JA, Vilgalys R, Aime MC, Aptroot A, Bauer R, Begerow D, Benny GL, Castlebury LA, Crous PW, Dai Y-C, Gams W, Geiser DM, Griffith GW, Gueidan C, Hawksworth DL, Hestmark G, Hosaka K, Humber RA, Hyde K, Ironside JE, Kõljalg U, Kurtzman CP, Larsson K-H, Lichtwardt R, Longcore J, Miądlikowska J, Miller A, Moncalvo J-M, MozleyStandridge S, Oberwinkler F, Parmasto E, Reeb V, Rogers JD, Roux C, Ryvarden L, Sampaio JP, Schüßler A, Sugiyama J, Thorn RG, Tibell L, Untereiner WA, Walker C, Wang Z, Weir A, Weiß M, White MM, Winka K, Yao Y-J, Zhang N (2007) A higher-level phylogenetic classification of the Fungi. Mycological Research 111: 509-547. https://doi.org/10.1016/j.mycres.2007.03.004

Kirk PM (2015) Species Fungorum (version Feb 2014). In: Roskov Y, Abucay L, Orrell T, Nicolson D, Kunze T, Flann C, Bailly N, Kirk P, Bourgoin T, DeWalt RE, Decock W, De Wever A (Eds) Species 2000 \& ITIS Catalogue of Life. Species 2000: Naturalis, Leiden. http://www.catalogueoflife.org/col. Accessed on: 2015-7-30.

Lowy B (1971) Flora Neotropica. Monograph 6. Tremellales. Hafner Publishing Company, New York, 153 pp.

Lowy B (1981) A new species of Dacryopinax from Brazil. Mycotaxon 13: 428-430.

McNabb RFR (1964) Taxonomic studies in the Dacrymycetaceae I. Cerinomyces Martin. New Zealand Journal of Botany 2: 415-424. https://doi.org/10.1080/0028825x.1964.10428762

McNabb RFR (1965a) Taxonomic studies in the Dacrymycetaceae II. Calocera (Fries) Fries. New Zealand Journal of Botany 3: 31-58. https://doi.org/10.1080/0028825x.1965.10428712

McNabb RFR (1965b) Taxonomic studies in the Dacrymycetaceae III. Dacryopinax Martin. New Zealand Journal of Botany 3: 59-72. https://doi.org/10.1080/0028825x.1965.10432062

McNabb RFR (1965c) Taxonomic studies in the Dacrymycetaceae IV. Guepiniopsis Patouillard. New Zealand Journal of Botany 3: 159-169. https://doi.org/10.1080/0028825x.1965.10876992

McNabb RFR (1965d) Taxonomic studies in the Dacrymycetaceae V. Heterotextus Lloyd. New Zealand Journal of Botany 3: 215-222. https://doi.org/10.1080/0028825x.1965.10428722

McNabb RFR (1965e) Taxonomic studies in the Dacrymycetaceae VI. Femsjonia Fries. New Zealand Journal of Botany 3: 223-228. https://doi.org/10.1080/0028825x.1965.10428723

McNabb RFR (1966) Taxonomic studies in the Dacrymycetaceae VII. Ditiola Fries. New Zealand Journal of Botany 4: 546-558. https:// doi.org/10.1080/0028825x.1966.10430183

McNabb RFR (1973) Taxonomic studies in the Dacrymycetaceae VIII. Dacrymyces Nees ex Fries. New Zealand Journal of Botany 11: 461-524. https://doi.org/10.1080/0028825x.1973.10430296

Meijer AAR (2006) Preliminary list of the macromycetes from Brazilian state of Paraná. Boletim do Museu Botânico Municipal 68: $1-55$.

Oberwinkler F (2014) Dacrymycetes. In: D.J. McLaughlin and J.W. Spatafora (eds.). Systematics and Evolution, 2nd ed. The Mycota VII Part A. Springer-Verlag, Berlin, 357-372.

Shirouzu T, Hirose D, Tokumasu S (2009) Taxonomic study of the Japanese Dacrymycetes. Persoonia 23: 16-34. http://doi.org/d7nt65 
Shirouzu T, Ishikawa NK, Hirose D, Maekawa N (2013) A new Amazonian species of Calocera with dendroid and multi-headed basidiocarp. Mycoscience 54: 252-256. http://doi.org/b966

Sobestiansky G (2005) Contribution to a macromycete survey of the states of Rio Grande do Sul and Santa Catarina in Brazil. Brazilian Archives of Biology and Technology 48: 437-457. https://doi org/10.1590/s1516-89132005000300015

Sotão HMP, Campos EL, Costa SPSE, Melo OA, Azevedo JC (2002) Basidiomycetes macroscópicos de manguezais de Bragança, Pará, Brasil. Hoehnea 29: 215-224.
Teixeira AR (1945) Himenomicetos brasileiros: Auriculariales e Dacrymycetales. Bragantia 5: 153-180. http://doi.org/b965

Trierveiler-Pereira L, Baltazar JM, Loguercio-Leite C (2009) Santa Catarina Island mangroves 4-Xylophilous basidiomycetes. Mycotaxon 109: 107-110. https://doi.org/10.5248/109.107

Viégas AP (1945) Alguns fungos do Brasil VI: Dacrymycetaceae-Tremellaceae. Bragantia 5: 239-251. http://doi.org/brrhrq

Worrall JJ, Anagnost SE , Zabel RA (1997) Comparison of wood decay among diverse lignicolous fungi. Mycologia 89: 199-219. https:// doi.org/10.2307/3761073 